\title{
PENGEMBANGAN KELEMBAGAAN TRADISIONAL MASYARAKAT DAERAH SEBAGAI PENYANGGA HUTAN UNTUK PELESTARIAN TAMAN NASIONAL GUNUNG HALIMUN SALAK (TNGHS)
}

\begin{abstract}
The background of this research is the fact that there are creative potentials of Indonesian community should be optimally discovered by ways of developing cultural and environmental society. This research takes a caseof National Park of Mounts of HalimunSalak (Taman Nasional Gunung Halimun-Salak; TNGHS). Through those activities the communitites around those areas have risen their economic lives and also actively participated in preserving environment and culture. This research identifies the development of potentials which are not optimally ascertained but should be realized by all related people to take the advantages of them. This research uses descriptive method which is done qualitatively. The study finds out that TNGHS is situated within the range of social planning. This model is not based on local initiatives, rather it is built on the social arrangements performed by formal and informal forces harmoniously sinergized to run social roles of TNGHS.
\end{abstract}

Key words: Community Development, Creative Economy, Sustainable Develovment.

\begin{tabular}{c}
\hline Agus Rusmana, Edwin Rizal, Ute \\
Lies Khadijah dan Rully K. Anwar \\
E-mail: rully.khairul@unpad.ac.id \\
\hline
\end{tabular}

Dosen FIKOM Universitas Padjadjaran

\section{A. Pendahuluan}

Nilai-nilai budaya luhur (cultural heritage) yang kental terwarisi, seperti teknologi tinggi pembangunan candi, batik, songket, wayang, pencak silat, dan seni budaya lain yang menjadi asset bangsa Indonesia. Tercatat pula tujuh lokasi yang dijadikan situs pusaka dunia (world heritage site). Belum lagi tingkat keragaman hayati (biodiversity) yang sukar ditandingi. Begitu pula spesies yang khas dan tak dapat dijumpai di wilayah lain di dunia, seperti komodo, orang utan, cendrawasih, dll. Termasuk kekayaan budidaya rempah-rempah seperti cengkeh, lada, teh, jahe, pala, dll.

Jawa Barat sendiri memiliki potensi itu semua yang dapat dikembangkan menjadi potensi yang dapat memberikan kesejahteraan bagi masyarakat. Potensi Jawa Barat yang demikian kaya dengan budaya dan 
lingkungan hidup menjadi menarik karena potensi-potensi tersebut masih perlu digali dan dikembangkan secara optimal sehingga mampu memberikan manfaat yang maksimal untuk kesejahteraan.

Isu kesejahteraan masyarakat dalam pengelolaan sumberdaya alam mulai mendapat respon, namun tidak bersifat struktural, dari pemerintah. Hal ini tercermin dari berbagai program yang berorientasi untuk membantu pendapatan masyarakat lokal, seperti program rehabilitasi lahan dan tanaman, dan program wanatani (agroforestry). Tetapi hasil pelaksanaan dari program-program tersebut sangat jarang mencapai apa yang diinginkan oleh masyarakat, karena hampir semua programprogram tersebut lahir dari kebijakan yang masih bersifat reaktif, yaitu lebih menanggapi masalah setelah masalah itu berkembang menjadi sulit untuk ditangani dibandingkan bila masalah tersebut dicegah sebelum timbul.

Kebijakan-kebijakan ini jarang dikoordinasikan dengan putusanputusan pembangunan ekonomi yang biasanya ikut membentuk arah sifat pengelolaan sumberdaya alam. Hal ini disebabkan oleh sistem ekonomi politik Indonesia yang melatarbelakangi konsep pembangunan yang bertumpu pada pertumbuhan ekonomi. Konsep tersebut memandang sumberdaya alam sebagai sumberdaya dengan nilai yang tidak terbatas dan mudah didapat. Konsep tersebut juga menjadi salah satu faktor lahirnya hegemoni negara atas sumberdaya alam, yang kemudian melahirkan Hak Menguasai Negara (HMN).

Bagi masyarakat adat dan masyarakat lokal, kondisi tersebut di atas dapat menyebabkan mereka kehilangan sumber bahan pangan, sandang, obat-obatan, bahan baku industri rumah tangga dan bahan baku kegiatan spiritual. Hilangnya sumberdaya tersebut selanjutnya dapat mengakibatkan hilangnya pengetahuan dan praktek tradisional yang kemudian mengakibatkan berubahnya tatanan sosial masyarakat adat.

Setelah sekian lama menghadapi berbagai tekanan, masyarakat adat dan masyarakat lokal mendesak kuat pemerintah untuk segera menghormati, menghargai, melindungi dan mengakui konsep pengelolaan sumberdaya alam yang mereka terapkan selama ini sebagai suatu paradigma baru dalam pembangunan. Di lapangan, sistem ini telah terbukti dapat mempertahankan keberlanjutan secara ekologi, sosial, budaya dan ekonomi.

Berdasarkan berbagai kondisi riil tersebut di atas, hal yang perlu mendapatkan prioritas perhatian adalah keterkaitan kondisi sosial budaya dan lingkungan masyarakat daerah-daerah tersebut dalam merespon derap pembangunan nasional dan pengaruh cepatnya gerak globalisasi. Kiranya tidak dapat dipungkiri lagi, bahwa faktor perilaku manusia sangat menentukan bagi pengembangan dan pemberdayaan masyarakat.

Dari berbagai persoalan sosial budaya dan lingkungan yang menjadi faktor determinan bagi kelangsungan hidup masyarakat, faktor sosial budaya tampaknya juga memberikan harapan bagi daya dukung pengembangan masyarakat (community development). Unsur sosial budaya yang memiliki potensi cukup strategis untuk membangun "kesadaran kolektif" masyarakat daerah sangatlah signifikan bagi pengembangan masyarakat setempat. 
"Kesadaran kolektif" dan "solidaritas sosial" biasanya mudah dibangun melalui sarana "kelembagaan sosial" yang sudah ada (Rahman \& Yuswadi, 2000). Pemanfaatan kelembagaan tradisional tersebut diharapkan dapat menjadi sarana yang efektif jika disesuaikan dengan definisi masyarakat tentang kelembagaan yang dimilikinya. Makna subyektif masyarakat terhadap budaya dan lingkungan yang dimilikinya juga memiliki posisi sentral bagi kelangsungan pembangunan masyarakat tersebut.

Kawasan Taman Nasional Gunung Halimun Salak (TNGHS) merupakan Kawasan Ekosistem Halimun merupakan kawasan pegunungan di Jawa Barat yang memiliki kekayaan keanekaragaman hayati yang tinggi. Sistem pengelolaan sumberdaya alam yang telah dikembangkan masyarakat adat maupun masyarakat lokal, sejak lama merupakan suatu sistem pengelolaan sumberdaya alam yang berorientasi pada kepentingan masyarakat lokal/adat yang tinggal di dalam dan atau di sekitarnya, dan kelestarian daya dukung lingkungan dengan cara mengembangkan pola pengelolaan sumberdaya alam yang berasaskan pada prinsip-prinsip desentralisasi, peran serta masyarakat dan keberlanjutan (sustainability) Namun saat ini, sistem tersebut telah mengalami beberapa penurunan. Kerusakan flora dan fauna yang melanda Taman Nasional akhir-akhir ini tidak terlepas dari kondisi daya dukung lingkungan sosial ekonomi dan budaya manusia yang berada di sekitarnya. Keutuhan ekosistem kawasan sangat ditentukan oleh sumberdaya alam dan sumberdaya manusia yang ada di daerah penyangga. Faktor pola penggunaan lahan, luas lahan pertanian, jumlah penduduk, mata pencaharian dan tingkat pemahaman masyarakat tentang kawasan konservasi akan sangat membantu dalam pelestarian dan pemanfaatan hutan secara berkelanjutan.

Berbagai bentuk pemanfaatan sumberdaya alam di dalam kawasan TNGHS umumnya telah berlangsung sejak sebelum ditetapkannya kawasan tersebut sebagai taman nasional. Beberapa kegiatan pemanfaatan sumberdaya alam di TNGHS yang penting, antara lain: pemanfaatan lahan untuk pemukiman, budidaya pertanian, penambangan (emas, panas bumi, dan galena), pembangunan infrastruktur (SUTET, jalan kabupaten dan propinsi, desa), dan pemanfaatan hasil hutan di dalam kawasan TNGHS.

Praktek pemanfaatan sumberdaya alam yang kurang mempertimbangkan daya dukung lingkungan dapat memicu terjadinya bencana alam di kawasan TNGHS, mengingat karakteristik alamnya menunjukkan adanya titik-titik rawan bencana, antara lain: banjir, tanah longsor, gempa bumi, uap/gas beracun, letusan gunung berapi, dan kebakaran hutan. Bencana alam dapat menimbulkan resiko sosial ekonomi yang membutuhkan biaya besar.

Selain itu, kerusakan kawasan Taman Nasional Gunung Halimun Salak (TNGHS) yang semakin parah pada akhir-akhir ini telah dianggap melampaui ambang batas toleransi. Padahal Taman Nasional ini merupakan salah satu kawasan hutan yang memiliki posisi strategis, karena merupakan daerah perlindungan bagi sumberdaya hayati, flora, dan fauna yang cukup potensial. Pertambahan penduduk yang sangat pesat di sekitar kawasan, serta terjadinya reformasi politik tahun 1998 yang lalu, memilki dampak ikutan 
terhadap kerusakan hutan Taman Nasional ini, akibat penjarahan oleh penduduk. Kerusakan tersebut diperkirakan akan semakin parah, jika tidak segera dilakukan penanganan yang serius oleh semua pihak.

Faktor lain yang tampaknya ikut memberikan kontribusi bagi terjadinya kerusakan hutan Taman Nasional Gunung Halimun Salak (TNGHS) tersebut adalah faktor sosial budaya masyarakat setempat. Rendahnya tingkat pendidikan, lemahnya penegakan hukum, kurangnya kesadaran lingkungan, dan faktor kemiskinan masyarakat daerah penyangga, semakin mempercepat terjadinya perusakan hutan Taman Nasional tersebut. Paradigma pembangunan dari rezim Orde Baru yang memprioritaskan pertumbuhan pada akhirnya hanya melahirkan eksploitasi besar-besaran terhadap sumber daya alam, menjamurnya konglomerasi, serta kesenjangan sosial.

Berdasarkan berbagai kondisi real tersebut di atas, hal yang perlu mendapatkan prioritas perhatian adalah keterkaitan kondisi sosial budaya masyarakat daerah penyangga Taman Nasional tersebut dalam merespon keberadaan Taman Nasional sebagai sumber kehidupan yang mempengaruhinya. Kiranya tidak dapat dipungkiri lagi, bahwa faktor perilaku manusia sangat menentukan bagi kelestarian hutan Taman Nasional.

Dari berbagai persoalan sosial budaya yang menjadi faktor determinan bagi kerusakan hutan Taman Nasional, faktor sosial budaya tampaknya juga memberikan harapan bagi daya dukung pelestarian hutan Taman Nasional Gunung Halimun Salak (TNGHS). Pemanfaatan kelembagaan tradisional diharapkan dapat menjadi sarana yang efektif jika disesuaikan dengan definisi masyarakat tentang kelembagaan yang dimilikinya. Makna subyektif masyarakat terhadap Taman Nasional Gunung Halimun Salak (TNGHS) juga memiliki posisi sentral bagi pelestarian hutan yang ada di Taman Nasional tersebut. Beberapa permasalahan tersebut antara lain: 1) Bagaimana peran Sosial Budaya masyarakat daerah penyangga terhadap Taman Nasional Gunung Halimun Salak (TNGHS)? 2) Bagaimana sistem kelembagaan tradisional yang mampu mendukung bagi kelestarian Taman Nasional Gunung Halimun Salak (TNGHS)?

Berdasarkan pertanyaan penelitian diatas, penelitian ini bertujuan untuk: 1) Mempelajari karakteristik dan kinerja kelembagaan tradisional, khususnya kelembagaan yang terkait dengan aktifitas ekonomi di pedesaan, 2) Mempelajari berbagai program yang berkaitan dengan pengembangan ekonomi kerakyatan di pedesaan, khsususnya dari sisi pengembangan kelembagaannya, 3) Mempelajari struktur dan pola interaksi antar tiga pilar masyarakat yang terdiri dari kelembagaan sosial, ekonomi, dan politik; yang mendukung ekonomi kerakyatan di pedesaan, 4) Mendapatkan simpulsimpul kritis transformasi kelembagaan tradisional guna memperkuat ekonomi kerakyatan di pedesaan dalam konteks globalisasi ekonomi dan otonomi daerah, 5) Membuat model transformasi untuk kelembagaan ekonomi pedesaaan yang bercorak tradisional untuk menghadapi globalisasi ekonomi dan otonomi daerah.

\section{B. Tinjauan Pustaka}

Upaya penguatan pengembangan ekonomi masyarakat perlu dipandang sebagai suatu 
keharusan, dimana penguatannya merupakan salah satu titik perhatian dari studi kelembagaan. Membangun kelembagaan untuk memperkuat jaringan ekonomi kerakyatan di lingkungan industri kecil dan menengah yang berbasis sumberdaya Usaha Mikro Kecil dan Menengah (UMKM) setempat, adalah juga berarti mengembangkan budaya nonmaterial untuk meningkatkan dayasaing modal sosial (social capital). Dari kacamata ekonomi, penguatan kelembagaan usaha kecil dan menengah harus mempunyai makna peningkatan dayasaing ekonomi kerakyatan di lingkungan UMKM.

Jika kita gunakan kembali kata asalnya, institusi, kita dapati bahwa ia adalah salah satu konsep sosiologi yang paling luas digunakan dan mempunyai beberapa pengertian yang berlainan. Ada kalangan yang menggunakan konsep ini untuk merujuk kepada suatu organisasi seperti universitas, perpustakaan atau asosiasi. Ada pula yang menganggapnya sebagai organisasi khusus seperti penjara, rumah sakit dan sekolah berasrama (dikenal sebagai institusi total). Konsep ini pun dimaksudkan sebagai suatu pola perilaku yang telah menjadi kebiasaan (established), atau suatu pola hubungan sosial yang mempunyai cita-cita sosial tertentu.

Pengertian yang paling banyak digunakan dan diterima dalam bidang sosiologi adalah pengertian yang ketiga. Namun sosiolog dan antropolog masih belum mencapai kesepakatan tentang penggunaan konsep ini. E. Chinoy (Society, 1962) berpendapat bahwa istilah institusi perlu dikhususkan kepada pola perilaku yang telah disetujui. Oleh karena itu, istilah lain hendaklah digunakan untuk menunjukkan aspek-aspek organisasi perilaku dan kelompok-kelompok yang terlibat. Contoh institusi yang diberikan oleh Chinoy adalah hukum pembunuhan dan kebiasaan yang menentukan interaksi sosial seharihari.

A. W. Gouldner dan H. Gouldner dalam buku mereka Modern Sociology melihat institusi sebagai cara yang standard untuk mengatasi berbagai masalah masyarakat, seperti upacara penguburan. R. M. Maclver dan C. H. Page dalam buku mereka Society mencoba membedakan institusi dari persatuan. Institusi, bagi mereka adalah "established forms or conditions of procedure characteristic of group activity." Kelompok yang terlibat dalam tatacara yang diterima secara meluas itu dikenal sebagai persatuan. Jadi gereja adalah persatuan, sedangkan sembahyang dan bentuk-bentuk pemujaan adalah institusi. Demikian juga kesatuan sekerja adalah persatuan, dan tawar menawar secara kolektif dan pemogokan adalah institusi. Seorang individu bisa menjadi anggota persatuan, tetapi tidak bisa menjadi anggota suatu institusi.

Institusi sosial yang utama adalah institusi perkawinan, institusi politik, institusi pelajaran, institusi ekonomi, dan institusi agama. Tiaptiap institusi ini saling berkaitan dan masing-masing mempunyai fungsinya yang tersendiri. Institusi perkawinan, misalnya berfungsi mengontrol pola hubungan seks serta melahirkan generasi baru. Institusi ekonomi mempunyai fungsi untuk mengontrol produksi dan penggunaan barang dan layanan. Fungsi utama institusi pelajaran adalah mendidik anggota suatu kelompok serta melanggengkan warisan budaya sosialnya.

Demikian pula dengan konsep tradisi dimaksudkan sebagai jalan 
bagi masyarakat untuk merumuskan dan menanggapi persoalan dasar dari keberadaannya dimuka bumi ini, yaitu kesepakatan yang dicapai masyarakat mengenai soal hidup dan mati. Tradisi lebih bersifat imanen dalam situasi aktual agar serasi dengan realitas yang berubah, dan sekaligus transenden sehingga dapat berfungsi memberi orientasi dan legitimasi, sehingga dengan demikian tradisi dapat dipahami sama dengan kebudayaan (Hidayana, 1989). Sementara, dalam studi-studi yang dilakukan oleh para ahli antropologi, kelembagaan dimaknai sama dengan konsep pranata sosial (social intitution) yang berarti sistem nilai dan sistem norma dan hukum tidak tertulis yang menjadi acuan dan pengendali setiap individu dalam semua aktivitas untuk mencapai suatu tujuan khusus (Koentjaraningrat,1981; Naping, 2002). Pranata sosial dijelaskan dalam karyakarya antropologi merupakan bagian integral dari penjelasan kebudayaan secara umum (Kaplan, 1999; Keesing, 1981) yakni kebudayaan terdiri atas sistem kognisi yang merupakan pola bagi terbentuknya perilaku. Dalam konteks ini bagaimana sistem pengetahuan (kognisi) masyarakat tentang lingkungan alam, sistem kepercayaan yang berkaitan dengan lingkungan, bahkan dalam bentuknya yang lebih tradisional, kelembagaan dipahami dalam wujud mitologi, dan ungkapan dalam bentuk cerita rakyat.

Proses transformasi budaya haruslah menjadi penggerak proses modernisasi masyarakat pertanian. Paradigma ini sedikitnya mempunyai tiga aspek: (1) pengembangan agroindustri dimulai dengan mengutamakan pengembangan kompetensi sumberdaya manusia dan penguatan kelembagaan lokal; (2) menggunakan desa sebagai unit otonom terbawah sebagai wadah kegiatan; dan (3) pendekatan wilayah pedesaan itu dapat meningkatkan keterkaitan desa-kota baik keterkaitan barang (input pertanian, output pertanian, barang konsumsi), keterkaitan tenaga kerja, maupun keterkaitan modal. Ekonomi rakyat di lingkungan industri kecil dan menengah akhirnya sejalan dengan fokus utama pada pengembangan UKM. Sumber peningkatan produktivitas ekonomi kerakyatan di di lingkungan industri kecil dan menengah adalah melalui kegiatan investasi melalui pengembangan ekonomi kerakyatan-industrial yang didukung oleh investasi sumberdaya manusia, sarana dan prasarana fisik, serta investasi modal sosial melalui pengembangan kelembagaan. Pengembangan produktivitas ekonomi kerakyatan melalui pembangunan ekonomi kerakyatanindustri perlu didorong dengan menumbuhkan lembaga-lembaga tradisional yang modern, handal, dan mengakar pada budaya masyarakatnya.

\section{Metode Kajian}

Penelitian ini menggunakan pendekatan deskriptif kualitatif. Pendekatan kualitatif memfokuskan telaahnya pada makna-makna subyektif, pengertian-pengertian, metafor-metafor, simbol-simbol, dan deskripsi-deskripsi ihwal suatu kasus spesifik yang hendak diteliti. Pendekatan ini dipilih agar studi ini memperolah gambaran detail dan mendalam mengenai suatu gejala sosial tertentu yang bersifat fenomenologis. Berdasarkan tujuannya, penelitian ini termasuk dalam kategori penelitian deskriptif, yaitu penelitian yang berusaha menggambarkan rincian-rincian spesifik dari situasi, setting atau relasirelasi sosial yang berlangsung dalam 
lingkup subyek penelitian (Patton, 2002).

Penelitian ini menggunakan pendekatan kualitatif, berlokasi di Desa Sirna Resmi Kecamatan Cisolok, Kabupaten Sukabumi, Pemilihan ini di Gunung Halimun Salak ditemukan titik lokasi dalam kondisi hutan sekitar Taman Nasional Gunung Halimun-Salak (TNGHS). Data primer yang juga di dapat dari wawancara beberapa pihak yang terkait dengan kegiatan budaya dan lingkungan hidup di tiga tempat tersebut yaitu tokoh masyarakat di kawasan tersebut, warga sekitar yang terlibat aktif dalam berbagai kegiatan, pemerintahan kelurahan, hingga Dinas Pariwisata dan Budaya/dinas terkait lainnya serta pihak swasta yang turut aktif mendukung kegiatan tersebut.

Metode pengumpulan data lainnya yang digunakan dalam penelitian ini adalah wawancara mendalam (in-depth interview). Dalam wawancara dengan informan, beberapa informasi yang dipertanyakan antara lain: (a) latar belakang pendirian lembaga. (b) kegiatan-kegiatan lembaga strategi pemberdayaan (d) upaya untuk mempertahankan komunitas lembaga. Triangulasi data menggunakan triangulasi sumber data. Berdasarkan azas penelitian kualitatif, analisis data dilakukan di lapangan dan bahkan bersamaan dengan proses pengumpulan data.

\section{Hasil Kajian dan Pembahasan \\ 1. Kondisi Masyarakat Sekitar TNGHS \\ Masyarakat yang berada di} Kawasan Ekosistem Halimun tidak hanya masyarakat lokal, tetapi juga ada masyarakat adat yang dikenal dengan Masyarakat Kasepuhan. Untuk masyarakat Kasepuhan, mereka hidup dalam kelompok tersebar di berbagai kampung di sekitar Banten Selatan (Kabupaten Lebak), Sukabumi Selatan dan Bogor Selatan, di sepanjang lereng-lereng dan bukit-bukit di sekitar Kawasan Ekosistem Halimun.

Berawal dari filosofi hidup yang tertuang dalam suatu kepercayaan yang menganggap bahwa "Ibu Bumi, Bapak Langit" yang maknanya adalah keutuhan bumi beserta dengan segala isinya harus dijaga dengan seksama, sebab apabila ada salah satu unsur/makhluk yang dirusak akan mengakibatkan rusaknya keseimbangan proses Kawasan Ekosistem Halimun ini. Perwujudan dari upaya mencegah kerusakan tersebut, masyarakat kasepuhan memandang hutan dapat dibedakan berdasarkan fungsinya, menjadi:

a. Hutan Titipan (Leuweung Titipan)

b. Hutan Tutupan (Leuweung Tutupan)

c. Hutan Garapan (Leuweung Garapan)

Leuweung Titipan adalah kawasan hutan yang sama sekali tidak boleh diganggu oleh manusia. Kata titipan merupakan amanat dari para leluhur (karuhun) dan juga Tuhan (Gusti Nu Kawasa) untuk dijaga keutuhannya dan dipertahankan dari segala usaha dan ancaman dari pihakpihak luar. Leuweung Titipan ini biasanya berada di daerah atas pegunungan atau puncak. Bagi masyarakat kasepuhan, Leuweung Titipan bukan hanya sebagai hutan lindung, tetapi juga merupakan hutan perlindungan alam mutlak yang tidak boleh diganggu gugat dari awal sampai akhir. Hutan perlindungan alam mutlak menunjukkan keanekaragaman hayati yang tinggi, berfungsi sebagai daerah resapan air 
(Leuweung Sirah Cai) dan sebagai pusat keseimbangan ekosistem. Keberadaan Leuweung Titipan ini ditandai dengan adanya "larangan untuk masuk ke dalamnya" secara adat.

Leuweung Tutupan adalah kawasan hutan yang dicadangkan untuk daerah pemukiman masyarakat adat Kasepuhan di masa mendatang (awisan) dan alokasi lahan garapan (untuk huma dan kebun). Perpindahan pemukiman ini dilakukan berdasarkan "wangsit" yang diterima oleh Abah (pemimpin adat/sesepuh girang masyarakat Kasepuhan), dan umumnya dalam kurun waktu 30-40 tahun, masyarakat Kasepuhan berpindah tempat (kampung). Secara ekologi, kurun waktu 30-40 tahun merupakan suatu gambaran mengenai daya dukung alam untuk memenuhi kebutuhan hidup manusia dan kemampuan alam untuk memulihkan kembali daya dukungnya. Tutupan diibaratkan seperti sebuah pintu yang dapat dibuka dan ditutup untuk diolah. Leuweung Tutupan berada pada bagian tengah dari kawasan hutan adat. Manusia diperolehkan masuk hanya dengan tujuan pengambilan hasil hutan kayu dan non kayunya, untuk pemenuhan kebutuhan subsistem (tidak untuk eksploitasi), seperti kayu bakar, kayu untuk bangunan, rotan, damar, buah-buahan, umbi-umbian, obat-obatan, serat, dan lain-lain. Aturan adat mengharuskan dalam setiap penebangan satu batang pohon, harus diganti dengan pohon yang baru. Penebangan pohon tersebutpun dapat dilakukan setelah mendapatkan izin dari ketua adat, dan hanya untuk keperluan pembuatan rumah (rumah adat).

Leuweung Garapan adalah kawasan hutan yang telah dibuka menjadi lahan yang dapat diusahakan oleh masyarakat, baik untuk bersawah, berhuma/ladang atau kebun. Pengaturan lokasi garapan (apakah di bagian timur, Barat, Utara atau Selatan) ditentukan oleh Abah (Abah merupakan sebutan untuk pemimpin masyarakat Adat Kasepuhan). Pengelolaan huma/ladang dilakukan secara rotasi minimal 3 tahun sekali. Untuk daerah-daerah tertentu, penanaman padi huma/ladang tidak boleh dilakukan pada tempat yang sama untuk kedua kalinya, seperti pada Huma Serang (suci). Di samping pembagian pengelolaan hutan, baik masyarakat adat maupun mayarakat lokal yang hidup di Kawasan Ekosistem Halimun juga mengenal berbagai sistem agroforestri khas Jawa Barat lainnya seperti: Kebun Talun, Dudukuhan, dan Kebon Kayu. Sistem ini, di kawasan hutan adat biasanya berada di kawasan leuweung tutupan dan garapan.

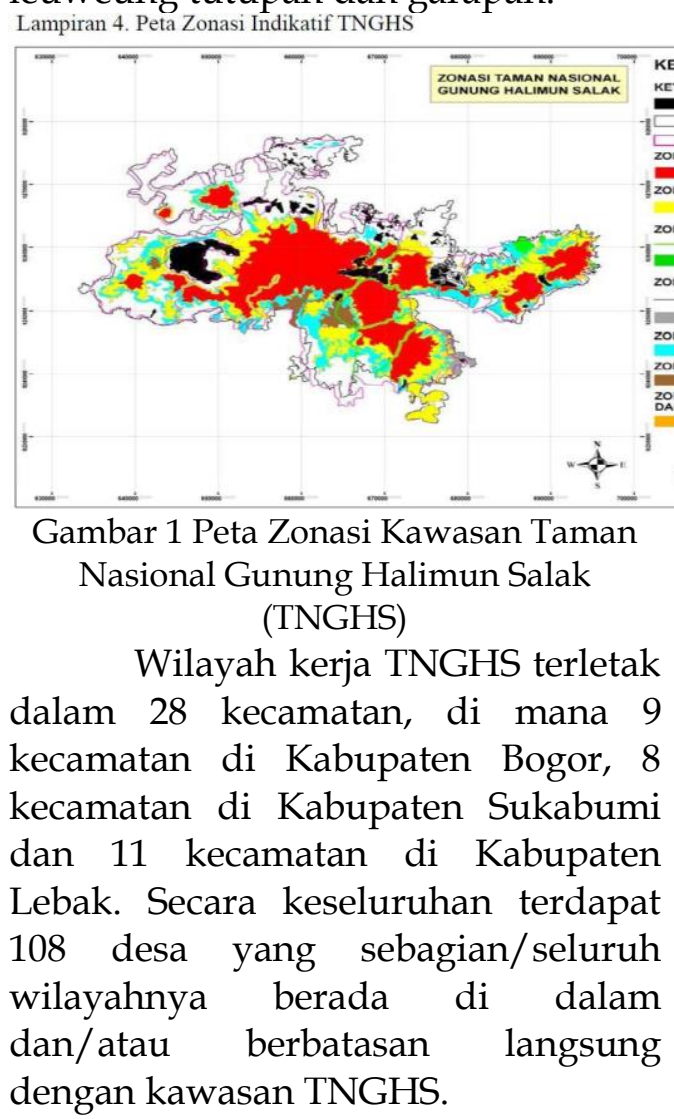


Komposisi jumlah penduduk dari 108 desa yang ada di TNGHS terdiri dari: 155.345 jiwa di Kabupaten Sukabumi (Tahun 2006), 296.138 jiwa di Kabupaten Bogor (Tahun 2005) dan 154.892 jiwa di Kabupaten Lebak (Tahun 2005). Berdasarkan survey kampung yang dilakukan oleh GHSNP MP-JICA pada tahun 2005 dan 2007, tercatat ada 348 kampung yang berada di dalam kawasan TNGHS.

Di TNGHS tinggal masyarakat kasepuhan yang secara historis penyebarannya terpusat di kampung Urug, Citorek, Bayah, Ciptamulya, Cicarucub, Cisungsang, Sirnaresmi, Ciptagelar dan Cisitu. Masyarakat Kasepuhan memiliki lembaga adat yang terpisah dari struktur administrasi pemerintahan formal (Desa). Masyarakat Kasepuhan memiliki kearifan tradisional dalam pemanfaatan dan konservasi hutan, melalui pembagian wilayah berhutan berdasarkan intensitas pemanfaatan dan tingkat perlindungannya, yaitu: leuweung titipan (hutan tutupan), leuweung tutupan (hutan tutupan) dan leuweung sampalan (hutan bukaan). Mereka memiliki pengetahuan etnobotani dan menggunakan tanaman atau tumbuh-tumbuhan di sekitar mereka berdasarkan pengetahuan tersebut, serta mempertahankan pola pertanian yang mampu melestarikan sumberdaya genetik padi (Oryza sativa) lokal. Pada saat ini sebagian anggota Masyarakat Kasepuhan mulai meninggalkan kearifan tradisional yang mereka miliki akibat dinamika proses sosial yang terjadi. Lemahnya pengakuan masyarakat terhadap eksistensi batas kawasan TNGHS di lapangan, serta belum selesainya proses tata batas dan zonasi TNGHS merupakan kendala bagi pengelola untuk mempertahankan kemantapan kawasan hutan dan menjalankan fungsi penegakan hukum yang dapat diterima semua pihak. Dari keseluruhan batas TNGHS sepanjang lk. $1280 \mathrm{~km}, 1170 \mathrm{~km}$ sudah ditata batas dan $1 \mathrm{k} 110 \mathrm{~km}$ belum ditata batas, yakni: di Blok Ciladaeun dan Cisimeut, Kabupaten Lebak (sepanjang lk $70 \mathrm{~km}$ ) dan Blok Cimaja, Kabupaten Sukabumi (sepanjang lk 40 $\mathrm{km})$. Rekontruksi batas masih perlu dilakukan agar batas kawasan TNGHS bebas konflik.

Kemampuan ekonomi masyarakat sekitar TNGHS cenderung rendah, walaupun sebagian besar tidak termasuk dalam kategori rumah tangga (RT) miskin. Secara umum jumlah RT miskin masyarakat di dalam dan di sekitar TNGHS dalam wilayah Kabupaten Sukabumi jumlah RT miskin berjumlah $15.699 \mathrm{RT}$ atau $10 \%$ dari jumlah RT (data tahun 2006, tidak termasuk Desa Cianaga), di kabupaten Bogor berjumlah 29.718 RT atau10 \% dari jumlah RT (data tahun 2005), sedangkan di Kabupaten Lebak berjumlah 22.696 RT atau $15 \%$ dari jumlah RT (data tahun 2005, tidak termasuk desa Wangun Jaya). Degradasi ekosistem hutan banyak terjadi di desa-desa yang berada di dalam dan sekitar kawasan TNGHS dan diduga terkait erat dengan rendahnya kemampuan ekonomi masyarakat.

Berbagai bentuk pemanfaatan sumberdaya alam di dalam kawasan TNGHS umumnya telah berlangsung sejak sebelum ditetapkannya kawasan tersebut sebagai taman nasional. Beberapa kegiatan pemanfaatan sumberdaya alam di TNGHS yang penting, antara lain: pemanfaatan lahan untuk pemukiman, budidaya pertanian, penambangan (emas, panas bumi, dan galena), pembangunan infrastruktur (SUTET, jalan kabupaten 
dan propinsi, desa), dan pemanfaatan hasil hutan di dalam kawasan TNGHS.

Di dalam kawasan TNGHS, beroperasi 2 perusahaan pertambangan, yaitu PT Aneka Tambang dan PT Chevron Geothermal Salak. PT Aneka Tambang melakukan penambangan emas di Cikidang (Kecamatan Cibeber, Kabupaten Lebak) dan Gunung Pongkor (Kecamatan Nanggung, Kabupaten Bogor), sedangkan PT Chevron Geothermal Salak melakukan penambangan panas bumi di kawasan Gunung Salak. Kedua perusahaan pertambangan tersebut mendapatkan izin pinjam pakai kawasan sebelum alih fungsi hutan lindung dan hutan produksi menjadi hutan konservasi (TNGHS). Kawasan TNGHS dikelilingi pula oleh perusahaan perkebunan yaitu PT. Nirmala Agung, PTPN VIII Cianten, PTPN VIII Cisalak Baru, PT Jayanegara, PT. Intan Hepta, PT. Yanita Indonesia, PT. Salak Utama, PT. Baros Cicareuh, PT. Hevea Indonesia (HEVINDO) dan PT. Pasir Madang. Selain itu, di sekitar kawasan TNGHS juga terdapat banyak perusahaan pengguna air, yaitu: industri air minum dalam kemasan, PDAM, industri makananminuman, pertambangan, perkebunan, peternakan, industri garmen, industri elektronik dan berbagai industri lainnya yang sumber mata airnya sangat dipengaruhi oleh keadaan ekosistem di dalam kawasan TNGHS.

Praktek

pemanfaatan sumberdaya alam yang kurang mempertimbangkan daya dukung lingkungan dapat memicu terjadinya bencana alam di kawasan TNGHS, mengingat karakteristik alamnya menunjukkan adanya titik-titik rawan bencana, antara lain: banjir, tanah longsor, gempa bumi, uap/gas beracun, letusan gunung berapi, dan kebakaran hutan. Bencana alam dapat menimbulkan resiko sosial ekonomi yang membutuhkan biaya besar.

Selain itu, kerusakan kawasan Taman Nasional Gunung Halimun Salak (TNGHS) yang semakin parah pada akhir-akhir ini telah dianggap melampaui ambang batas toleransi. Padahal Taman Nasional ini merupakan salah satu kawasan hutan yang memiliki posisi strategis, karena merupakan daerah perlindungan bagi sumberdaya hayati, flora, dan fauna yang cukup potensial. Pertambahan penduduk yang sangat pesat di sekitar kawasan, serta terjadinya reformasi politik tahun 1998 yang lalu, memiliki dampak ikutan terhadap kerusakan hutan Taman Nasional ini, akibat penjarahan oleh penduduk. Kerusakan tersebut diperkirakan akan semakin parah, jika tidak segera dilakukan penanganan yang serius oleh semua pihak.

Faktor lain yang tampaknya ikut memberikan kontribusi bagi terjadinya kerusakan hutan Taman Nasional Gunung Halimun Salak (TNGHS) tersebut adalah faktor sosial budaya masyarakat setempat. Rendahnya tingkat pendidikan, lemahnya penegakan hukum, kurangnya kesadaran lingkungan, dan faktor kemiskinan masyarakat daerah penyangga, semakin mempercepat terjadinya perusakan hutan Taman Nasional tersebut. Paradigma pembangunan dari rezim Orde Baru yang memprioritaskan pertumbuhan pada akhirnya hanya melahirkan eksploitasi besar-besaran terhadap sumber daya alam, menjamurnya konglomerasi, serta kesenjangan sosial.

Di samping beberapa persoalan tersebut di atas, potensi Sumber Daya Alam (SDA) di daerah 
penyangga tampaknya juga memiliki arti penting bagi kelestarian lingkungan Taman Nasional Gunung Halimun Salak (TNGHS). Jika kondisi SDA di daerah penyangga Taman Nasional memiliki daya dukung untuk mengakomodasi kebutuhan masyarakat (pangan, sandang, papan, dan lapangan kerja) yang ada disekitarnya, maka diperkirakan sentuhan atau gangguan terhadap SDA yang ada "di dalam" Taman Nasional akan dapat ditekan sekecil mungkin. Akan tetapi, sebaliknya kemungkinan akan terjadi, jika potensi SDA di daerah penyangga Taman Nasional tersebut tidak memadai bagi penduduk di sekitarnya, maka akibatnya terjadi penggerogotan, gangguan, dan bahkan penjarahan terhadap SDA di dalam Taman Nasional Gunung Halimun Salak (TNGHS).

Oleh karena itu pemahaman kondisi SDA di daerah penyangga Taman Nasional Gunung Halimun Salak (TNGHS) menjadi sangat penting. Potensi SDA di daerah penyangga Taman Nasional akan menjadi faktor penentu terjadinya tekanan penduduk terhadap SDA yang ada di dalam kawasan Taman Nasional. Jika tekanan penduduk lebih besar dari ketersediaan lahan garapan, maka kemungkinan besar akan terjadi tekanan yang kuat terhadap lahan Taman Nasional Gunung Halimun Salak (TNGHS).

\section{Pengembangan Masyarakat di TNGHS}

Dilihat dari bentuk kawasannya, Taman Nasional Gunung Halimun Salak berbentuk seperti bintang atau jemari, sehingga batas yang mengelilingi kawasan taman nasional ini menjadi lebih panjang. Pengelolaan kawasan seperti ini lebih sulit dibandingkan dengan pengelolaan kawasan yang berbentuk relatif bulat. Apalagi di dalamnya terdapat beberapa enklave berupa perkebunan, permukiman masyarakat tradisional serta beberapa aktivitas pertambangan emas, pembangkit energi listrik panas bumi dan pariwisata. Termasuk pula permukiman-permukiman

masyarakat adat Kasepuhan Banten Kidul.

Banyak para petani tradisional maupun pendatang sudah tinggal di wilayah ini sebelum kawasan ini ditetapkan sebagai areal konservasi. Sehingga menjadi tantangan pengelola, para pihak dan masyarakat lokal dalam mengembangkan model pengelolaan kawasan TNGHS yang lebih kolaboratif dan berkelanjutan.

Dengan mengacu pada derajat saling mempengaruhi antara masyarakat dan pemerintah, maka apa yang terjadi di TNGHS bisa dikategorikan berada pada tahap engaging (keikutsertaan). Dalam konteks ini, maka yang perlu dilakukan oleh pihak pemerintah dan masyarakat adalah melakukan dialog dan konsensus dalam pengembangan hutan. Inisiatif yang datang dari pemerintah, masyarakat adat, dan masyarakat yang lain perlu dipertemukan untuk kemudian dicari kata yang sama dalam pengembangan hutan.

Seluruh warga masyarakat dalam model ini terlibat sebagai aktor penting dalam perubahan sosial. Mereka memiliki peran yang tidak dapat dianggap kecil. Keberadaan masyarakat adat hingga hari ini bertahan karena berbagai kelompok sosial dan masyarakat umum yang masih memiliki kepedulian akan bertahannya warisan alam di TNGHS. Keberadaan masyarakat adat gunung dalam ruang lingkup Jawa Barat memang sangat unik dan langka. 
Seluruh wisatawan yang mengunjungi TNGHS merupakan konsumen yang menikmati wisata alam-budaya. Sebagai konsumen mereka disuguhkan keindahan natural-sosial terkait TNGHS dan masyarakat pendukungnya. Generasi muda khususnya para pendaki gunung merupakan konsumen penting yang memiliki peran penting dalam transmisi ekologis dari tempat ini. Mereka menjadikan TNGHS sebagai wahana pembelajaran alamsosial. Hal yang lebih penting adalah TNGHS sebagai wahana untuk melakukan alih generasi kekayaan alam dan budaya yang terus dilakukan kepada generasi muda. Ini sangat bermanfaat untuk kepentingan jangka panjang. Sekitar 15-20 tahun mendatang, generasi muda tersebut kelak akan menjadi penerus dan pemimpin bangsa yang mesti bertanggung jawab terhadap kelangsungan hidup masyarakat dan alam yang mereka pimpin.

Masyarakat adat kasepuhan Banten Kidul yang tinggal di sekitar TNGHS sampai saat ini masih mempunyai karakteristik budaya yang khas. Dimana setiap tahun setelah panen padi mereka mengadakan kegiatan adat yang disebut seren taun sebagai ungkapan rasa syukur atas keberhasilan dalam pertanian khususnya padi yang merupakan makanan pokok masyarakat. Kegiatan seren taun selain untuk warga kasepuhan juga dapat disaksikan oleh masyarakat umum lainnya termasuk untuk kunjungan wisata budaya karena banyak kegiatan menarik yang dapat dilihat. Jadwal pelaksanaannya antara bulan Juni-Desember setiap tahun, tergantung perhitungan waktu masing-masing kelompok kasepuhan. Beberapa seren taun yang menarik untuk dikunjungi dan dilihat adalah seren taun di kasepuhan Ciptagelar, Sirnaresmi, Ciptamulya, Cicarucub, Cisitu, Cisungsang, Citorek dan Urug. Masyarakat setempat masih memegang teguh memegang adat istiadat yang diwariskan leluhur mereka dan diyakini bahwa arwah leluhur sebagai penghuni alam gaib yang mengendalikan kehidupan. Hal ini terlihat dari tata cara mereka memohon restu kepada leluhur sebelum penanaman padi dilaksanakan agar diberikan hasil panen yang melimpah atau dijauhkan dari hama penyakit.

Pelepasan nadar (permohonan sesuatu) yang berhubungan dengan nasib dan keberuntungan dilakukan oleh masyarakat melalui suatu upacara kecil (selamatan) yang dilaksanakan didalam salah satu halaman komplek bangunan Situs pada bagian susunan kelompok menhir yang diberi pagar dan atap.

$\begin{array}{cc}\text { Kelangsungan } & \text { keberadaan } \\ \text { TNGHS tidak semata-mata }\end{array}$
ditentukan oleh pihak pemerintah maupun masyarakat sekitarnya, tetapi juga dapat dilibatkan pihak eksternal lainnya seperti peneliti, analis maupun fasilitator lapangan. Mereka dapat dilibatkan secara independen maupun secara resmi oleh pihak pemerintah. Pihak eksternal ini dapat memberikan berbagai masukan penting untuk program-program yang dapat dilaksanakan oleh masyarakat penyangga TNGHS. Peneliti dari universitas dapat dilibatkan untuk berbagai penelitian yang hasilnya dapat menjadi rekomendasi bagi keberlangsungan program-program budaya-ekologis tersebut.

Fasilitator lapangan juga dapat dilibatkan dengan berbagai ide maupun program yang menarik, inspiratif dan mencerdaskan masyarakat sebagai konsumen. 
Mahasiswa tingkat akhir yang memiliki concern dan komitmen dengan pengembangan budaya dapat dilibatkan dalam program pengembangan budaya dan kelestarian alam. Dengan cara ini, keterlibatan mereka sebagai pekerja sosial dapat menjadikan TNGHS semakin menarik.

Berdasarkan fungsi yang harus dijalankan dari tatali piranti karuhun, sebaran Masyarakat Kasepuhan tersebut, Kasepuhan Sinarresmi, Ciptagelar, Cisungsang, Cisitu, Cicarucup, Citorek dan Bayah merupakan kelompok Kasepuhan utama. Salah satu indikasi yang menunjukan tentang "keutamaan" kelompok Kasepuhan tersebut adalah banyaknya perwalian. Sebagai contoh Kasepuhan Ciptagelar - dulu dikenal sebagai Kasepuhan Ciptarasa membawahi 560 perwalian Kasepuhan dari tiap-tiap desa di tiga kabupaten (Lebak, Sukabumi dan Bogor). Selain dari Bogor, Sukabumi dan Lebak, pengikut kasepuhan juga berasal dari beberapa daerah lain. Banyak tidaknya pengikut dalam suatu kelompok Kasepuhan sangat mungkin juga dipengaruhi oleh kebiasaan berpindahnya kampung gede Kasepuhan (sebagai pusat orientasi sosio-kultural dan politik Masyarakat Kasepuhan) tersebut.

Bahasa yang umum digunakan oleh masyarakat lokal adalah bahasa Sunda dan mayoritas penduduknya beragama Islam walau masih terdapat yang menganut kepercayaan lama. Masyarakat kasepuhan di TNGHS merupakan bagian dari warisan budaya nasional. Mereka masih memegang teguh adat kebudayaan nenek moyangnya terlihat dalam keseragaman kehidupan sehari-hari, arsitektur rumah, sistem pertanian dan interaksi dengan hutan.
Perubahan yang berlangsung di TNGHS dilakukan dengan cara penentuan masalah dan keputusan melalui tindakan rasional para ahli. Temuan lapangan menunjukkan bahwa keterlibatan pihak ahli sangat penting untuk semakin mendinamiskan peran sosial TNGHS. Peran sosio-edukasi yang berlangsung di TNGHS selama ini berlangsung cukup efektif dalam membangun kesadaran akan pentingnya budaya berbasiskan alam tersebut. Meski demikian, minimnya Dana pengembangan kawasan hutan, berpengaruh pula pada hasil perubahan yang diharapkan.

Demi kepentingan survival, saat ini, masyarakat setempat memanfaatkan hutan dan lahan sekitarnya dalam berbagai cara, yaitu seperti huma/ladang (swidden cultivation), sawah (rice growing), kebun (garden), kebuntalun (mixed garden) dan talon (mixed forest). Masyarakat memiliki kearifan tradisional yang sifatnya tutun temurun dalam pemanfaatan dan konservasi hutan, melalui pembagian wilayah berhutan berdasarkan intensitas pemanfaatan dan tingkat perlindungannya yaitu adanya 'leuweung titipan' (protected forest), 'leuweung tutupan' (conservation forest), atau 'leuweung sampalan' (opened forest). Mereka masih memiliki interaksi yang kuat dengan hutan sekitarnya. Masyarakat juga memiliki pengetahuan etnobotani dan menggunakan tanaman atau tumbuhtumbuhan di sekitar mereka berdasarkan pengetahuan tersebut, serta mempertahankan pola pertanian yang mampu melestarikan sumberdaya genetik padi (Oryza sativa) lokal. Pada saat ini sebagian anggota Masyarakat Kasepuhan mulai meninggalkan kearifan 
tradisional yang mereka miliki akibat dinamika proses sosial yang terjadi.

Perubahan paradigma pengelolaan hutan Kementerian Kehutanan akhir-akhir ini tampaknya mulai dapat memberikan angin segar bagi sistem pelestarian hutan di masa yang akan datang. Asumsi ini diharapkan dapat terealisasi jika paradigma tersebut dilaksanakan secara konsisten, terpadu, dan berkelanjutan. Paradigma kementerian dari semula bersifat sentralistik dan hanya memperhatikan aspek ekonomi telah diubah dengan arah yang lebih mengutamakan keseimbangan ekologi, ekonomi dan sosial budaya masyarakat di sekitarnya. Rehabilitasi hutan dan lahan merupakan strategi pemerintah dalam mengembangkan pemberdayaan ekonomi rakyat melalui sistem setempat (community based forest management) yang sekaligus merupakan upaya penyelamatan kelestarian hutan.

Transformasi kesadaran sosioedukasi yang berlangsung di TNGHS tidak secara langsung terjadi sebagaimana lazim dilakukan pendidikan formal di dalam kelas yang hanya bersifat dua arah. Pendekatan yang terjadi melalui pendidikan model orang dewasa (andragogi) yang menjadikan individu sebagai orang yang aktif dan terlibat dinamis dalam pembangunan ekologi. Hal yang penting juga adalah adanya perumusan kebijakan dan perencanaan program yang dapat memperkuat pemberdayaan sosial yang dilakukan masyarakat sekitar TNGHS.

Secara realistis, kerusakan Taman Nasional Gunung Halimun Salak (TNGHS) di luar faktor-faktor yang bersifat alamiah, tampaknya tidak terlepas dari akibat campur tangan manusia. Tingkat pemahaman, perhatian, serta kepedulian masyarakat terhadap keberadaan Taman Nasional, banyak dipengaruhi oleh tingkat perkembangan sosial budaya masyarakat yang bersangkutan. Aspek-aspek struktural maupun kultural seringkali sangat berpengaruh terhadap persepsi maupun kepedulian masyarakat daerah penyangga terhadap Taman Nasional Gunung Halimun Salak (TNGHS). Tingginya kesenjangan sosial akibat adanya stratifikasi sosial, dan polarisasi sosial merupakan suatu situasi yang perlu diwaspadai bagi kelestarian Taman Nasional Gunung Halimun Salak (TNGHS). Bertahannya nilai-nilai dan normanorma sebagai perwujudan budaya masyarakat, memiliki makna yang strategis bagi upaya-upaya pelestarian lingkungan Taman Nasional Gunung Halimun Salak (TNGHS).

\section{Pembahasan}

\section{a. Karakteristik Kelembagaan Tradisional}

Kasepuhan Sinar Resmi adalah suatu komunitas dengan segala kearifan lokalnya yang dalam kesehariannya, menjalankan sosio budaya tradisional yang mengacu pada karakteristik budaya Sunda. Kasepuhan Sinar Resmi merupakan satu dari sebelas kasepuhan yang berada di wilayah Banten Selatan. Komunitas ini hidup secara turun temurun dari generasi ke generasi yang masih dipelihara dan diperkuat sebagai perwujudan rasa syukur dan penghormatan kepada para leluhur. Masyarakat adat Kasepuhan Sinar Resmi menata seluruh kehidupannya baik sebagai individu maupun sebagai kelompok sosial dan religius yang khas, yang berbeda antara satu dengan yang lainnya. Sistem-sistem inilah yang dipertahankan dan 
diperjuangkan sebagai sumber semangat hidup yang tekandung dalam sistem adat yang masih dibudayakan dan dilestarikan.

Masyarakat adat Kasepuhan Sinar Resmi tidak pernah terlepas dari filosofi-filosofi hidup yang sudah menjadi satu jiwa pada diri masyarakat kasepuhan sendiri. Filosofi inilah yang menjadi pedoman hidup masyarakat. Dalam kehidupan bermasyarakat, basis dari hukum adat kasepuhan adalah filosofi hidup, "tilu sapamulu, dua sakarupa, hiji eta-eta keneh", yang secara harfiah artinya 'tiga se wajah, dua se rupa, satu yang itu juga". Selain pedoman dalam bersosialisasi antar masyarakat, masyarakat kasepuhan memiliki interaksi dengan alam. Melalui filosofi "Ibu bumi, bapak langit, tanah ratu" yang intinya dalam kehidupannya, masyarakat harus menjaga keutuhan bumi beserta segala isinya sehingga keseimbangan alam pun tetap terjaga.

Berdasarkan filosofi-filosofi inilah masyarakat kasepuhan memiliki keyakinan untuk terus menjaga apa yang sudah diwariskan oleh para leluhurnya, baik menjaga hubungan dengan manusia lain dan menjaga hubungan dengan alam. Salah satu warisan leluhur yang masih diterapkan dalam kehidupan masyarakat kasepuhan adalah sistem pertanian ladang/huma (rurukan) dan sawah yang dilakukan satu kali dalam satu tahun. Sistem pertanian ini tidak sekedar sebuah kegiatan pertanian yang secara umum menuju pada produktivitas, namun sistem pertanian di masyarakat adat Kasepuhan Sinar Resmi lebih berorientasi pada suatu interaksi yang kuat antar masyarakat dengan Tuhan, masyarakat dengan masyarakat serta masyarakat dengan alam. Dalam pengelolaan sistem pertanian, mulai dari mempersiapkan lahan sampai pada mengistirahatkan lahan kembali selalu diikuti dengan rangkaian upacara atau ritual adat yang menyertainya yang sudah diwariskan oleh para leluhur.

Rencana pembangunan yang akan dilaksanakan di komunitas adat perlu disosialisasikan terlebih dahulu kepada publiknya dalam hal ini masyarakat itu sendiri. Salah satu sarana yang dapat dijadikan sosialisasi adalah pertemuan rutin rukun tetangga. Pada pertemuan yang dilakukan setiap bulan ini, merupakan kesempatan bagi camat dan stafnya untuk mensosialisasikan program pembangunan komunitas adat.

Sebagai kecamatan yang berada di pinggiran Kabupaten Sukabumi, Kecamatan Cisolok yang berpenduduk 43800 jiwa (BPS Kabupaten Sukabumi, 2012). Komunitas adat dikategorisasikan sebuah komunitas yang ada dipinggiran oleh globalisasi: pertama, sebagian wilayahnya lebih kecil atau sama dari sebuah dusun namun pengaruh modernisasi jelas terlihat dalam tatanan kehidupan masyarakat di sekitar komunitas adat. Terkait dengan potensi ekonomi komunitas yang mereka miliki, ada beberapa aspek ekonomi menonjol yang berhasil digali secara mendalam dan secara potensi dapat dikembangkan sebagai basis kehidupan ekonomi masyarakat Sinarresmi utamanya dalam hal menjaga kearifan lokal adat dan sumber pendapatan mereka. Fasilitas angkutan menuju lokasi termasuk mudah dijangkau. Oleh karena itu komunitas adat yang merupakan tempat yang sedang berproses untuk perubahan. Kedua, kondisi komunitas adat Sinarresmi sebagian wilayahnya sudah dipakai oleh pembangunan yang yang dibangun oleh dinas kehutanan. 
Keberadaan pemerintahan daerah dalam memantau komunitas adat dalam aspek penggunaan tanah dan aspek politik yang dinilai masyarakat sebagai salah satu mesin politik yang bisa digerakkan.

\section{b. Pengembangan Kelembagaan}

Kehidupan pertanian (ladang dan sawah) masih menjadi ciri utama kehidupan masyarakat di sekitar TNGHS ini. Masyarakat kasepuhan umumnya tidak memiliki tanah pribadi di luar kawasan, sekalipun punya letaknya di dalam kawasan. Mata pencaharian utama masyarakat kasepuhan adalah pertanian padi baik huma maupun sawah. Ada masyarakat yang bermata pencaharian sebagai petani ada yang sebagai buruh tani. Buruh tani di Kasepuhan mempunyai tanah garapan (sawah/ huma) tapi jumlahnya sedikit, maka dia menjadi buruh setelah tanahnya selesai digarap, atau men-jadi buruh untuk tanahnya sendiri. Buruh murni tidak ada, yang betul-betul buruh dan tidak punya tanah. Upah buruh tani sistemnya 5:1 untuk padi, sedangkan kalau dibayar dengan uang sebesar Rp. 30.000 per hari dari jam 08.00-15.00.

Dalam hal menggarap lahan pertanian padi, kedudukan laki-laki dan perempuan (suami dan istri) seimbang, saling bekerja sama, ada bagian yang harus dikerjakan oleh laki-laki dan ada bagian yang harus dikerjakan oleh kaum perempuan. Misalnya dalam hal ngasek (melobangi tanah), tugas laki-laki adalah melobangi tanah, selanjutnya perempuan yang memasukan padinya ke lubang. Pada saat habis panen padi, tanah ditanami oleh palawija (mentimun, buncis, jagung, ikan), sampai datang masa menanam padi lagi. Tanaman padi utama adalah huma, sedangkan sawah hanya pendamping.

Masyarakat kasepuhan menanam padi-padian lokal yang mereka sebut pare ageung. Mereka mengenal tidak kurang dari 100 spesies padi. Namun umumnya masyarakat memanfaatkan sekitar 50 spesies. Masyarakat Kasepuhan Sirna Resmi masih memelihara cara bertani tradisional. Mereka menggarap tanah dan menanamnya setahun sekali. Hal itu mereka lakukan demi penghormatan kepada Ibu Bumi. "Masa, Ibu dipaksa melahirkan dua kali setahun. Yang benar saja," demikian prinsip Abah Asep. Bumi ini adalah makhluk hidup. Karena itu tradisi mengajarkan tentang ritus pertanian. Sebelum mengolah tanah, mereka lakukan upacara. Menurut keyakinan mereka, untuk mengolah tanah perlu pamit dulu atau permisi karena bumi ini adalah makhluk yang telah dikotori. Itulah yang mereka lakukan.

Secara resmi agamanya Islam dan ada sebuah masjid di tengah kampung. Namun mereka masih memberikan ritus atau sesajian buat Dewi Sri. Padi dalam konsep kasepuhan dimaknai sebagai Dewi Sri (Ibu), sehingga mulai dari tanam sampai panen dan memasak dan memakannya menggunakan tata cara penghormatan tertentu. Ada banyak upacara adat yang berhubungan dengan pertanian padi, misalnya pada saat akan memulai kegiatan pertanian harus meminta izin terlebih dahulu kepada abah. Setelah abah mendapatkan wangsit barulah memberikan izin kepada incu putu untuk melakukan kegiatan pertanian secara serentak pada bulan tertentu yang sudah ditetapkan oleh adat. Dalam setiap kegiatan pertanian juga terdapat berbagai macam upacara ritual, misalnya pada saat memilih 
bibit, dilakukan upacara ritual dengan cara membakar kemenyan dan melantunkan do'a, begitupun pada saat menabur benih.

Pada saat membuka ladang, selain membakar kemenyan juga menyediakan tumpeng. Upacara ritual yang mirip perlakuannya di dalam ritual manusia adalah pada saat mapag pare nyiram (yaitu saat pohon padi mulai berbunga). Pada upacara ini tanaman padi diperlakukan seperti wanita yang sedang hamil 7 bulan, karena itu upacara juga diwarnai dengan penyediaan rurujakan 7 macam rujak, bubur merah dan putih, dan dilakukan doa selamatan seperti pada manusia, seperti membaca surat Yusuf dan Surat Maryam. Tujuan dari upacara ini agar padi yang mulai berbuah tadi selamat dan menghasilkan biji padi yang banyak. Selanjutnya, sebelum panen, setelah panen (nganyaran padi) juga dilakukan upacara berupa penyediaan kemenyan, kopi, rokok dan kue serta doa-doa. Upacara terbesar adalah pada saat memasukkan padi ke lumbung yang disebut upacara seren tahun. Upacara ini dilakukan selama 3 hari - 3 malam oleh seluruh incu putu yang langsung dipimpin oleh Abah.

\section{c. Kelembagaan Sosial}

Masyarakat Kasepuhan

Sinarresmi adalah masyarakat berbentuk komunitas yang tidak seluruhnya berdomisili di tempat di mana ketua adat berada yaitu di Desa Sirnaresmi, Kecamatan Cisolok, Kabupaten Sukabumi. Anggota komunitas Kasepuhan Sinarresmi tersebar di beberapa lokasi di luar Desa Sirnaresmi, namun masih berada di seputar wilayah Taman Nasional Gunung Halimun Salak. Banyak juga anggota masyarakat Kasepuhan
Sinarresmi ini yang tinggal di lokasi tempat tinggal. Ketua Adat Kasepuhan Cisungsang atau Ciptagelar.

Secara administratif, warga masyarakat adat Kasepuhan Sinarresmi memiliki hak dan kewajiban yang sama dengan warga lain umumnya. Mereka yang berdomisili di wilayah desa Sirnaresmi juga wajib tercatat secara resmi sebagai warga dan wajib mengikuti semua peraturan kependudukan yang berlaku seperti memiliki misalnya Kartu Penduduk, dan tercatat dalam Kartu Keluarga. Sebaliknya mereka juga mendapat hak pelayanan yang sama seperti hak memilij dalam kegiatan pemilihan kepala desa, pemilihan bupati, gubernur dan presiden. Mereka juga mendapat hak pelayanan kesehatan seperti pelayanan di Puskesmas atau rumah sakit rujukan.

Dalam menjalani kehidupan sosialnya, anggota masyarakat adat Kasepuhan Sinarresmi menggunakan dua kelembagaan sosial, yaitu kelembagan sosial masyarakat resmi yang sudah diatur oleh pemerintah Republik Indonesia, dan kelembagaan sosial yang dibuat dan diberlakukan untuk seluruh anggota masyarakat adat Kasepuhan. Salah satunya adalah pernikahan, Seperti masyarakat umumnya, pelaksanaan pernikahan warga masyarakat adat dilaporkan tercatat secara resmi oleh Kantor Urusan Agama Kecamatan dimana mereka tinggal, dalam hal ini adalah Kecamatan Cisolok, Kabupaten Sukabumi. Namun untuk seluruh pelakasanaan kegaiatan yang berkaitan dengan adat dan kebiasaan, seluruh anggota masyarakat adat kasepuha harus mengikuti adat istiadat yang dibuat dan diberlakukan oleh kasepuhan, seperti permintaan ijin menikah kepada Ketua Adat 
Kasepuhan, upacara pernikahan dan persyaratan adat pernikahan lainnya. Upacara adat dilaksanakan setelah seluruh persyaratan menikah yang diwajibkan oleh Kantor Urusan Agama Kecamatan telah terpenuhi. Diputuskan oleh masyarakat adat bahwa urusan yang berkaitan dengan peraturan pemerintah harus didahulukan.

\section{d. Kelembagaan Ekonomi}

Mata pencaharian utama anggota masyarakat adat Kasepuhan Sinarresmi, baik yang berdomisili di Desa Sirnaresmi maupun di wilayah lain di sekitar Taman Nasional adalah bertani, terutama petani sawah. Terdapat dua model pertanian yang digunakan yaitu pertanian sawah dan huma. Pertanian sawah dilakukan oleh masyarakat di persawahan milik pribadi, sedangkan pertanian huma dilakukan disembarang tempat yang dapat ditanami di sekitar tempat tinggal mereka.

Tidak seperti kelembagaan ekonomi umumnya, masyarakat adat Kasepuhan Sinarresmi mengelola hasil pertanian dan mata pencaharian secara adat. Tidak ada sistem koperasi atau sistem pengelolaan perdagangan lain yang digunakan. Yang menarik dalam sistem pengelolaan adat ini adalah adanya prinsip ekonomi yang dapat menunjang kehidupan ekonomi masyarakat adat. Makna prinsip ini adalah pemerataan berazaskan kekeluargaan. Artinya walaupun seorang warga masyarakat adat kasepuhan tidak memiliki sawah sendiri, tetapi dia rajin bekerja, dia tetap akan dapat memiliki padi dari hasilnya membantu panen di sawah anggota masyarakat adat yang memiliki sawah. Jika dia tidak mendapatkan kesempatan dan kemampuan mendapat padi, jika dia rajin membantu bekerja menggiling padi, maka dia akan akan mendapat bagian beras. Jika ternyata dia tidak sempat bekerja untuk mendapatkan beras, dia tetap akan bisa makan karena semua warga masyarakat adat akan selalu bersedia memberinya makan. Prinsip kekeluargaan ini menyebabkan tidak adanya kasus rawan pangan dimana seorang warga masyarakat yang kelaparan karena tidak mampu membeli bahan makanan pokok.

Prinsip perekonomian lain yang menunjang teraminnya kehidupan anggota masyarkat adalah prinsip yang dikenal oleh masyarakat umum sebagai "menabung' / menghinpun persediaan. Prinsip yang berasal dari peraturan adat ini mengatur bahwa apabila hasil panen hanya mencukupi untuk memenuhi kebutuhan pangan untuk tiga tahun, maka seluruh hasil panen hanya digunakan untuk keperluan sendiri. Jika hasil panen melebihi kebutuhan pangan untuk tiga tahun, maka kelebihan itu dapat dijual. Dengan prinsip ini maka kebutuhan pokok makan minimal (makan nasi) akan dapat selalu terpenuhi, baik untuk mereka yang memiliki sawah maupun yang sama sekali tidak dapat menghasilkan bahan pangan apapun. Untuk menghindari pertentangan di antara warga adat, maka seluruh padi dan beras yang merupakan persediaan untuk tiga tahun mendatang, disimpan di tempat penyimpanan yang berada di rumah ketua adat, dalam penelitian ini adalah rumah Ketua Adat Kasepuhan Sinarresmi di Desa Sirnaresmi, Kecamatan Cisolok, Kabupaten Sukabumi.

\section{e. Kelembagaan Politik}

Warga masyarakat adat Kasepuhan Sinarresmi yang berdomisili di Desa Sirnaresmi 
dibebaskan oleh kepala adat untuk ikut berpolitik. Artinya mereka dibebaskan untuk ikut berpolitik praktis, misalnya dalam kegiatan pemilihan kepala desa, mereka boleh ikut berkampanye untuk mendukung seorang calon. Kebebasan yang sama juga diberikan ketika mereka ingin mendukung calon bupati Sukabumi. Namun demikian, sesuai peraturan adat, kampanye politik tidak boleh diadakan di sekitar perkampungan adat Kasepuhan Sinarresmi dimana ketua adat bertempat tinggal di Desa Sirnaresmi. Untuk menjaga netralitas, ketua adat kasepuhan Sinarresmi tidak memberikan dukungan secara terbuka atau resmi kepada salah satu calon dalam sebuah kampanye, baik dalam pemilihan kepala desa maupun bupati. Namun ketua adat juga tidak menolak kehadiran calon kepala desa maupun calon bupati yang datang berkunjung untuk menemuinya sepanjang tidak dalam rangka berkampanye. Begitu juga rumah adat di wilayah kampung adat tidak diperobolehkan digunakan sebagai posko salah satu partai politik. Prinsip keterbukaan ini membuat kehidupan politik di sekitar kampun adat dapat berjalan lancar.

Hubungan antara kepala adat Kasepuhan Sinarresmi dengan tokoh politik, anggota DPRD, Camat Cisolok dan Bupati Sukabumi berlangsung dengan baik. Dari fotofoto yang terpampang di dalam rumah ketua adat kasepuhan dapat diketahui bahwa Ketua Adat Kasepuhan Sinarresmi memiliki hubungan yang baik dengan pejabat daerah di Sukabumi dan pejabat daerah lainnya. Di dalam ruang pertemuan di dalam rumah ketua adat, terpampang lukisan Bupati Purwakarta, foto Kapolda Jawa Barat dan beberapa pejabat pemerintah lainnya. Begitu juga plakat-plakat yang merupakan kenang-kenangan yang diberikan oleh lembaga pemerintah yang pernah berkunjung ke rumah ketua adat.

\section{f. Ekonomi Kerakyatan}

Seiring perkembangan zaman dan laju pertumbuhan di segala bidang menyikapi hal tersebut, maka salah satu program prioritas di lingkungan Kesatuan Adat Banten Kidul mengadakan Acara Ritual Adat Seren Taun yang merupakan sikap responsif terhadap aspirasi masyarkat disekitar Kasepuhan Sinar Resmi, sebagai bukti peran aktif dalam rangka upaya meningkatkan kualitas sumber daya manusia dan menghormati warisan leluhur yaitu dengan cara Mempertahankan ciri adat kebudayaannya.

Desa Sirna Resmi merupakan wilayah pusat kasepuhan. Penduduknya tinggal dalam kampung-kampung kecil yang biasanya terdiri dari 10-30 rumah membentuk pola pemukiman the farm village type menurut istilah Smith dan Zopf (1970) dengan ibukota desa sebagai perkampungan terbesar.

Terdapat prinsip keadilan dalam pelaksanaan sistem kelembagaan ekonomi masyarakat adat, yaitu bahwa warga yang rajin bekerja dan kreatif, akan mendapatkan lebih banyak penghasilan daripada yang bekerja biasa saja atau yang malas. Contohnya adalah sistem pertanian huma. Karena huma tidak dimiliki oleh perorangan, maka siapa yang paling dahulu dan paling banyak menanam akan mendapat hasil pertanian yang paling banyak. Penghasilan yang diperoleh karena kerajinannya ini akan diperolehnya penuh tanpa kekhawatiran adanya penyerobotan oleh warga lain yang malas tetapi ingin mendapat lebih. 
Adanya jaminan untuk selalu terpenuhi kebutuhan pokoknya membuat warga masyarakat adat Kasepuhan Sinarresmi tidak melakukan tindakan lain untuk mendapatkan hasil lebih, sepertinya misalnya perambahan hutan di Taman Nasional. Hal ini membuat seluruh tanaman di bagian hutan Taman Nasional Gunung Halimun Salak tidak terganggu. Kalaupun ada pertanian huma yang dilakukan di wilayah taman nasional, sifatnya tidak merusak hutan namun hanya penanaman di wilayah terbuka yang memang sudah biasa digarap. Namun demikian memang masih terdapat persoalan ketika terdapat kegiatan yang dilakukan oleh pengelola taman nasional yang dilakukan melalui tanah milik masyarakat adat, atau kegiatan masyarakat adat yang dilakukan di wilayah taman nasional.

\section{E. Kesimpulan}

Dari hasil penelitian diketahui bahwa masyarakat dalam hal ini masyarakat sebagai salah satu stake holder dalam proses pembangunan pedesaan di Kecamatan Cisolok ternyata memainkan peranan yang sangat signifikan, berupa pemunculan ide-ide, identifikasi dan perumusan masalah, pelaksanaan hingga evaluasi yang terkadang dilaksanakan bersama-sama dengan lembaga desa seperti LKMD dan BPD. Media sosial sebagai suatu media komunikasi yang hidup dan berkembang di masyarakat, memungkinkan terjadinya integrasi antara pihak-pihak yang berkomunikasi sehingga dapat juga sebagai media komunikasi pembangunan. Menipisnya kepercayaan kepada pengurus desa menjadi penghambat terciptanya komunikasi yang dialogis. Media pertemuan di tingkat desa yang tidak secara rutin terselenggara dan sistem perwakilan (memungkinkan terjadinya distorsi pesan) menyebabkan masyarakat merasa enggan untuk mengungkapkan permasalahan-permasalahan yang dihadapi.

Pola kerjasama pengembangan kekayaan budaya yang dimungkinkan berdasar prinsipprinsip sebagai berikut: 1) formal, artinya ada satu kesepakatan yang sifatnya mengikat, 2) berkelanjutan, memiliki dimensi jangka panjang dan simultan, dan 3) partisipatif, artinya melibatkan semua pelaku (stakeholder), meliputi: masyarakat, pemerintah, swasta, mediator, tokoh budaya/masyarakat.

Model kerjasama yang dilakukan harus memiliki sifat: 1) tidak harus seragam, artinya satu model tidak harus cocok untuk semua situasi dan kondisi tempat; 2) adanya standar minimal, yaitu memiliki unsur-unsur pokok, yaitu para pelaku, mekanisme kerja dan program utama, dan jangka waktu tertentu; dan 3) dinamis, yaitu memiliki kemungkinan dan fleksibilitas untuk disesuaikan dengan berbagai perubahan-perubahan yang terjadi.

Dalam peta pembangunan, Taman Nasional Gunung Halimun Salak (TNGHS) berada pada ranah perencanaan sosial. Model ini tidak lagi berbasiskan inisiatif lokal, tetapi dibangun atas perencanaan sosial yang dilakukan oleh berbagai kekuatan formal maupun informal. Keduanya menjalin sinergi yang harmonis dalam mendinamiskan peran sosial TNGHS. 
F. Daftar Pustaka

Anonim. 1999. Kerangka Acuan Rehabilitasi Kawasan Taman Nasional Gunung Halimun Salak (TNGHS). Jember: Balai Taman Nasional Gunung Halimun Salak (TNGHS).

Anonim. 2000. Statistik Kehutanan Balai Taman Nasional Gunung Halimun Salak (TNGHS). Jember: Balai Taman Nasional Gunung Halimun Salak (TNGHS).

Bamberger, M. (Ed.). 2000. Integrating Quantitative and Qualitative Research in Development Projects. Directions in Development, Washington DC: The World Bank.

Bangun, Wilson. 2010. Teori Ekonomi Mikro. Bandung: Refika Aditama.

Bottomore, T. B., Classes in Modern Society, Holt, Rinehart and Winston, London, 1971.

Bottomore, T.B., Elites and Society, Peguin Book, Hammonds worth, 1966.

Bottomore, T. B., Sociology: A Guide to Problems and Literature, G. Allen \& Unwin, London, 1962.

Box, Steven, Deviance, Reality and Society, Holt, Rinehart and Winston, London, 1971.

Cahyono, Tri, Bambang. 1983. Pengelolaan Sumber Daya. Yogyakarta: Liberty. Yogyakarta.

Clinard, M. B. (ed), Anomie and Deviant Behaviour, Free Press, New York, 1964.

Cohen, Percy, Modern Social Theory, Heinemann, London 1968.

Comte, A., The Positive Philosophy, Trubner, London, 1853.

Coser, L., The Functions of Social Conflict, Routledge \& Kegan Paul, London, 1956.
Coser, Lewis \& Rosenberg, Bernard (eds.), Sociological Theory A Book of Readings, Macmillan, New York, 1969.

Coser, Lewis, Masters of Sociological Thought, Harcourt Brace Jovanovich, New York, '1971.

Coughlin, Richard, Double Identity: The Chinese in Modern Thailand, Hong Kong University Press, Hong Kong, 1960.

Cox, O.C. Caste, Class and Class and Race, Montly Review Press, New York, 1959.

Dahrendorf, R., Class and Class Conflict in Industrial Society, Routledge \& Kegan Paul, London, 1959.

Davison, G. dan Mc Conville, C. 1991. A Heritage Handbook. St. Leonard, NSW: Allen \&Unwin.

Deliarnov. 2007. Perkembangan Pemikiran Ekonomi. Jakarta: Raja Grafindo Persada. Jakarta.

Durkheim, Emile, The Division of Labour in Society, Free Press, New York, 1964.

Durkheim, Emile, The Rules of Sociological Method, Free Press, New York, 1964.

Gerth, H. H. \& Mills, C. Wright (eds), From Max Weber: Essays in Sociology, Routledge \& Kegan Paul, London, 1970.

Gibbs, J. P. "The Study of Norm," International Encyclopedia of the Social Sciences, Vol. 11, Macmillan \& Free Press, New york, 1968.

Giddens, A. (ed.), Positivism and Sociology. Heinemann, London, 1974.

Goeltenboth, Friedhelm, 1992. "Kerusakan Hutan dan Implikasi bagi Kesinambungan Daya Dukung Lingkungan. Prisma, No.6, Tahun XXI. Jakarta: LP3ES. 
Hardcastle, D. A., Powers, P.R., and Wenocur, S. 2004. Community practice: theories and skills for social workers -2nd ed. New York: Oxford University Press.

Herskovits, M. J., Cultural Anthropology, Knopf, New York, 1955.

Hikmat, Harry. 2005. Strategi Pemberdayaan Masyarakat. Bandung: Humaniora Utama Press.

Howard, A. M., Caste: A Comparative Study, Russel \& Russell, New York, 1968.

Identifikasi Sosial Ekonomi Budaya Masyarakat Sekitar Penyangga Taman Nasional Gunung Halimun Salak (TNGHS), Laporan Penelitian. Balai Pengelolaan DAS SampeanMadura, Balai Taman Nasional Gunung Halimun Salak (TNGHS) dan Universitas Jember. Tahun 2002.

Iriantara, Yosal. 2004. Community Relations: Konsep dan Aplikasinya. Bandung: Simbiosa Rekatama Media.

Ishomuddin. 2002. Pengantar Sosiologi Agama. Jakarta: Ghalia Indonesia.

Karmadi, Agus Dono, Budaya Lokal Warisan Budaya dan Upaya Pelestariannya. (Makalah tidak dipublikasikan).

Linton, R. (ed.), The Science of Man in the World Crisis, Columbia University Press, New York, 1945.

Linton, Ralph, The Study of Man, Appleton Century, New York, 1936.

Lipset, S.M. \& Bendix, R., Social Mobility in Industrial Society, University of California Press, Berkeley, 1959.

Lipsey, Richard G., dkk. 1988. Ilmu Ekonomi. Jakarta: Bina Aksara.
MacIver, R. M. \& Page, D. H., Society: An introductory Analysis, Macmillan, New York, 1969.

Merton, Robert K., Social Theory and Social Structure, Free Press, New York, 1957.

Miller, S. M. "Comparative Social Mobility," Current Sociology, Vol. IX, No 1, 1960.

Mills, C. Wright, The Power Elite, Oxford University Press, New York, 1956.

Moleong, Lexy J. 1988. Metode Penelitian Kualitatif. Bandung: Rosdakarya.

Narwoko, J. Dwi, dkk. 2011. Sosiologi Teks Pengantar Dan Terapan. Bandung: Remaja Rosdakarya.

Nasution, S. 1985. Metode Research. Jakarta: Rineka Cipta.

Nasution, Zulkarnaen. 1988. Komunikasi Pembangunan: Pengenalan Teori dan Penerapannya. Jakarta: PT. Raja Grafindo Persada.

Neuman, Lawrence W. 1994. Social Research Methods: Qualitative and Quantitative Approaches. Boston: Allyn and Bacon.

Pareto, Vilfredo, The Mind and Society, Dover, New York 1963.

Parson, Talcott, The Social System, Routlege \& Kegan Paul, London, 1951.

Parsons, T. \& Shils, E., Towards a General Theory of Action, Harper, New York, 1962.

Patton, M. Q. 2002. Qualitative Research and Evaluation Methods. 3rd edition, London: Sage.

Pelly, Usman, 1993. Pengukuran Intensitas Potensi Konflik dalam Masyarakat Majemuk, Analisis CSIS, Th.XXII, No. 3, Mei - Juni.

Philipus, Ng., dkk. 2006. Sosiologi dan Politik. Jakarta: RajaGrafindo Persada. 
Pitana, I. Gede dan Putu G. Gayatri. 2005. Sosiologi Pariwisata. Yogyakarta: Andi.

Popper, Karl, Poverty of Historicism, Routledge \& Kegan Paul, London, 1961.

Punch, K. F. 1998. Introduction to Social Research: Qualitative and Quantitative Approaches. London: Sage Publications.

Radcliffe Brown, A.R., Structure and Function in Primitive Society, Cohen \& West, London, 1968.

Rahman, Bustami dan Yuswadi, Hary. 2000. Sistem Sosial Budaya Indonesia. Jember: Laboratorium Kajian Pemberdayaan MasyarakatFISIP-Universitas Jember.

Rescher, N. "On Prediction and Explanation", English Journal of the Philosophy of Science, 8, hlm. 281-290, 1958.

Rex, John, "The Plural Society in Sociological Theory", English Journal of Sociology, Vol. 10, No. 2, 1959.

Rex, John, Key Problems of Sociological Theory, Routledge \& Kegan Paul, London, 1961.

Rex, John, Race Relation in Sociological Theory, Weidenfeld \& Nicolson, London, 1970.

Riesman, D. et.al., The Lonely Crowd, Yale, University Press, New Haven, 1950.

Robertson, Roland (ed.), Sociology of Religion, Penguin Books, Harmondsworth, 1969.

Rothman, J., \& Tropman, J. 1987. Models of community organization and macro practice perspectives: Their mixing and phasing. In F. Cox, J. Erlich, J. Rothman, \& J. Tropman (Eds.), Strategies of community organization (4th ed., pp. 3-26). Itasca, IL: P. E. Peacock.
Runcimanm W.G., Relative Deprivation and Social Justice, Routledge \& Kegan Paul, London, 1966.

Smith, L. 1996. "Significance Concepts in Australian Management Archaeology" dalam L. Smith dan A. Clarke (eds). Issues in Management Archaeology. Tempus, vol 5.

Smith, M.G., The Plural Society in the English West Indies, University of California Press, Berkeley, 1965.

Srinivas, M.N., Caste in Modern India and Other Essays, Asia Publishing House, Bombay, 1962.

Suharto, Edi. 1997. Pembangunan, Kebijakan Sosial dan Pekerjaan Sosial: Spektrum Pemikiran. Bandung: Lembaga Studi Pembangunan STKS (LSPSTKS).

Suharto, Edi. 2005. Membangun Masyarakat Memberdayakan Rakyat-]Kajian Strategis Pembangunan Kesejahteraan Sosial dan Pekerjaan Sosial. Bandung: Reflika Aditama.

Suwarsono \& Alvin Y.So. 1994 Perubahan Sosial dan Pembangunan. Jakarta: LP3ES.

Tjokroamidjoyo, Bintoro. 1982. Pengantar Pemikiran tentang Teori dan Strategi Pembangunan Nasional, Jakarta: Gunung Agung.

Travers, Max. 2001. Qualitative Research Through Case Studies, London:Sage Publications.

Tylor, E. B., Primitive Culture, Murray, London 1929.

Usman, Sunyoto, 2001. Konflik dan Resolusi Konflik Sumberdaya Alam Perspektif Sosiologi, Pidato Pengukuhan Jabatan Guru Besar pada FISIP Universitas Gadjah Mada, Tanggal 15 September 2001 di Yogyakarta. 
Van den Berghe, P. L., Race and Racism, John Wiley, New York, 1967.

Weber, Max, The Methodology of the Social Sciences, Free Press New York, 1949.

Weber, Max, The Theory of Social and Economic Organization, Free Press, New York, 1947.

Wells, Alan (1970), Social Institutions, Heinemann, London, 1970.

Wicaksono, Andhie, Inisiatif Masyarakat dalam Pengembangan Wisata Budaya: Kasus Desa Miau Baru (tidak dipublikasikan).

Yoeti, Oka A. 1991. Pengantar Ilmu Pariwisata. Bandung: Angkasa.

Yogi, Ms. 2004. Ekonomi Manajerial. Jakarta: Kencana. 